\title{
Spatial Analysis of Land Susceptibility to Degradation and Alternative Plants for Its Rehabilitation
}

\author{
Diah Auliyani ", Tyas Mutiara Basuki, Wahyu Wisnu Wijaya \\ Watershed Management Technology Center, Jl. Jend. Ahmad Yani, Pabelan, Surakarta, 57102 \\ *) Corresponding Author (e-mail: d_auliyani@yahoo.com)
}

Received: 8 January 2019 / Accepted: 17 July 2019 / Published: 1 August 2019

\begin{abstract}
One of the drawbacks of developing plants for the rehabilitation of degraded land in Indonesia is the relative lack of information about species that are suited to the local conditions. Therefore, spatial information on land degradation and the plants suitable for rehabilitation is crucial. The objectives of this study were to map the susceptibility of land to degradation and to identify some alternative species for its rehabilitation. The research was conducted in Jang Watershed, Bintan Island, Kepulauan Riau Province, Indonesia. A quick assessment of land degradation was carried out to classify the degree of land susceptibility. The land suitability evaluation was conducted manually by matching the existing biophysical condition and plant growth requirements using a geographic information system. This analysis was applied for annual plants, such as Acacia mangium, Durio zibethinus, Artocarpus champeden, Theobroma cacao and Hevea brassiliensis. Furthermore, the maps of land susceptibility to degradation and species suitability were overlaid and the result was used to provide recommendations for rehabilitating the degraded land. This study showed that $22 \%$ of the Jang Watershed area can be categorised as highly susceptible to degradation. The suitability analysis illustrated that $59 \%$ of the degraded areas were suitable for Acacia mangium. The planting of fast-growing species such as Acacia mangium is expected to improve the physical, chemical and biological properties of the soil.
\end{abstract}

Keywords: degradation, land suitability, quick assessment.

Abstrak. Salah satu kelemahan dalam mengembangkan tanaman untuk rehabilitasi lahan terdegradasi di Indonesia adalah kurangnya informasi mengenai kesesuaian jenis dengan kondisi lahan setempat. Oleh karena itu, informasi spasial mengenai kerentanan degradasi lahan dan tanaman yang sesuai untuk rehabilitasinya sangat penting. Tujuan dari penelitian ini adalah untuk memetakan tingkat kerentanan lahan terhadap degradasi dan untuk menyediakan beberapa alternatif tanaman untuk kegiatan rehabilitasi. Penelitian ini dilakukan di Daerah Aliran Sungai (DAS) Jang, Pulau Bintan, Provinsi Kepulauan Riau, Indonesia. Sidik cepat degradasi lahan diterapkan untuk mengklasifikasikan tingkat kerentanan lahan. Evaluasi kesesuaian lahan dilakukan secara manual dengan mencocokkan kondisi biofisik yang ada dan persyaratan pertumbuhan tanaman menggunakan Sistem Informasi Geografis. Analisis ini diterapkan untuk tanaman tahunan, seperti Acacia mangium, Durio zibethinus, Artocarpus champeden, Theobroma cacao, dan Hevea brassiliensis. Selain itu, peta kerentanan lahan terhadap degradasi dan peta kesesuaian lahan ditumpangtindihkan untuk selanjutnya hasilnya digunakan sebagai rekomendasi untuk merehabilitasi lahan terdegradasi. Penelitian ini menunjukkan bahwa 22\% dari DAS Jang memiliki tingkat kerentanan degradasi lahan yang tinggi. Analisis kesesuaian menggambarkan bahwa 59\% daerah yang terdegradasi sesuai untuk Acacia mangium. Penanaman jenis pohon cepat tumbuh seperti Acacia mangium diharapkan dapat memperbaiki sifat fisik, kimia, dan biologi tanah.

Kata kunci: degradasi, kesesuaian lahan, sidik cepat. 


\section{Introduction}

Land degradation is the decline in the natural quality of the soil component within an ecosystem (Eni, 2012). The level of degradation is indicated by a decrease in vegetation cover (Mawardi, 2010) and the capacity of a watershed to store water (Narulita et al., 2008). In Indonesia, degraded lands result mainly from a mismatch or incompatibility between land use and its capability (Herrick et al., 2019; Wahyuningrum \& Basuki, 2014)Wonogiri District, Central Java. Mini catchment area of about 10.82 ha was used as unit analysis which was divided into land unit based on its biophysical characters. Dataused includeprecipitation, wetanddrymonthsof the year, soil type, soiltextureandstructure, effectivedepth, regolithdepth, slope, rock type, and thepercentage ofrockoutcropatthe surface, as well asdrainage. Universal Soil Lost Equation (USLE along with the over-use of land resources (Kubangun et al., 2014). In addition, land becomes degraded through intensive agricultural activities carried out without soil and water conservation measures, combined with disturbance to the water regulation function in a watershed (Nugroho \& Prayogo, 2008). As a result, degraded land must be rehabilitated, otherwise it will be a loss to the functionality of the ecosystem (Marchetti et al., 2018) and consequently contribute to an increase in the frequency of floods, landslides and drought (Hasan et al., 2016).

The recovery of degraded land through rehabilitation activities has been conducted for several decades; however, land degradation is still continuously taking place. This may be the result of a lack of integrated information on both land sustainability versus degradation and the species that are suitable for its rehabilitation. It is necessary to spatially classify the susceptibility of land to degradation in order to determine the priority in which to rehabilitate degraded land (Basuki \& Wahyuningrum, 2014). This classification can be conducted by analysing the properties of land obtained using remote sensing data (Basuki \& Wahyuningrum, 2016). These spatial data are essential in order to delineate degraded land (Tarigan, 2012).

In addition to spatial information related to degraded land, another important factor in terms of improving the success of land rehabilitation is the suitability of the species selected for planting on the land (Basuki \& Wahyuningrum, 2016; Pratiwi et al., 2014; Sudarmadji \& Hartati, 2016). As such, it is necessary to match the growth requirement of plants with the properties of the land in question.

The use of remote sensing data to determine the degree of degraded land has been carried out in several areas (Basuki \& Wahyuningrum, 2014; Basuki et al., 2016; Tarigan, 2012), while analysis of the suitability of species to degraded land has been undertaken at other sites (Pratiwi et al., 2014; Wahyuningrum et al., 2003). As mentioned previously, in order to achieve the successful rehabilitation of degraded land, information on the degree of land susceptibility to degradation must be integrated with the proper selection of species. Therefore, this study is essential in order to bridge the gap between those previous studies.

The main objective of this study were to map the susceptibility of land to degradation and to identify alternative species for its rehabilitation. In this study, we used free access IKONOS satellite imagery from Google Earth to obtain our land cover map. This imagery has been widely used for land cover classification due to its high spatial resolution ( $\mathrm{Hu}$ et al., 2013). In this paper, the imagery was not only used for land cover classification but also for the analysis of land susceptibility to degradation. In addition to land cover mapping, a land suitability analysis of various species was undertaken aimed at their potential use in land rehabilitation.

\section{Research Method}

This study was conducted in 2016 in Jang Watershed, Bintan Island, Kepulauan Riau 
province, Indonesia. Jang Watershed covers an area of 7910 ha, extending from $104^{\circ} 26^{\prime} 14^{\prime \prime}$ to $104^{\circ} 35^{\prime} 0^{\prime \prime}$ East longitude and $0^{\circ} 50^{\prime} 38^{\prime \prime}$ to $0^{\circ} 56^{\prime} 50^{\prime \prime}$ North latitude (Figure 1). Based on Schmidt and Fergusson's classification, the climate type is A with a $\mathrm{Q}$ value of $0 \%$ (Adi \& Wijaya, 2016). Mean annual rainfall is 3243 $\mathrm{mm}$ and mean monthly rainfall exceeds 200 mm with no dry months (Adi \& Wijaya, 2016). The elevation of the study area is $0-212 \mathrm{~m}$ above sea level and the land is characterised by flat to very steep slopes ranging from 0 to $52 \%$.

The materials used in this study were land cover maps derived from IKONOS Google Earth 2014, and the slope steepness data were derived from DEM/SRTM (Digital Elevation Model/ Shuttle Radar Topographic Mission). Data on the land system, landform, soil type, geomorphology and lithology were obtained from The Regional Physical Planning Programme for Transmigration (RePPProT). Rainfall data were obtained from the Meteorological, Climatological and Geophysical Agency in Tanjung Pinang (BMKG Tanjung Pinang). In this paper, we focus only on biophysical factors. The research outline is given in Figure 2.

A quick assessment of land degradation was undertaken to classify the degree of land susceptibility to degradation. This ground check was conducted in 2016. The data were analysed spatially by overlaying the required maps. The degree of land susceptibility to degradation was classified into very low (1), low (2), medium (3), high (4) and very high (5). The formulation of the susceptibility of land to degradation is shown in Table 1.

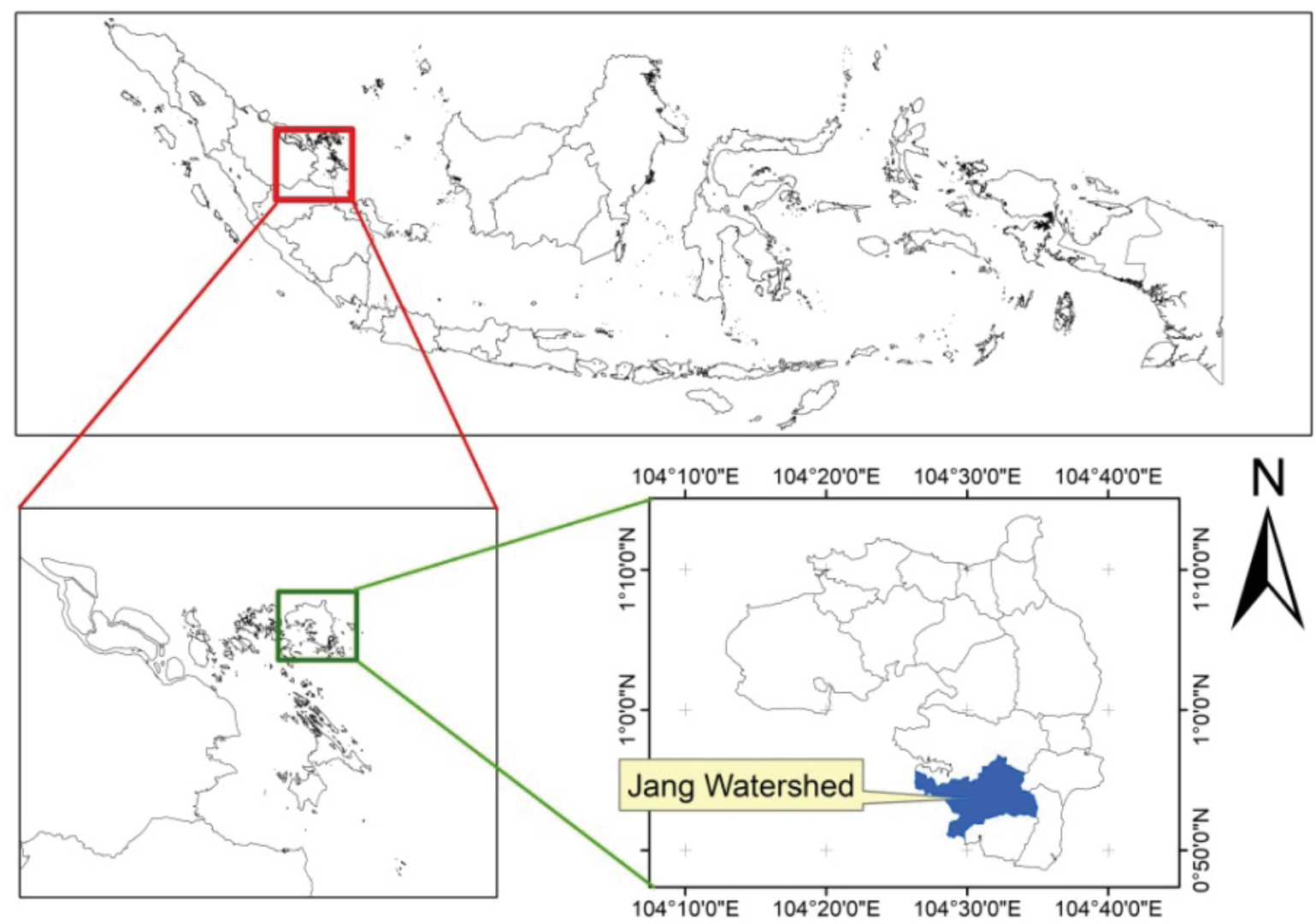

Figure 1. Location of the study area. 


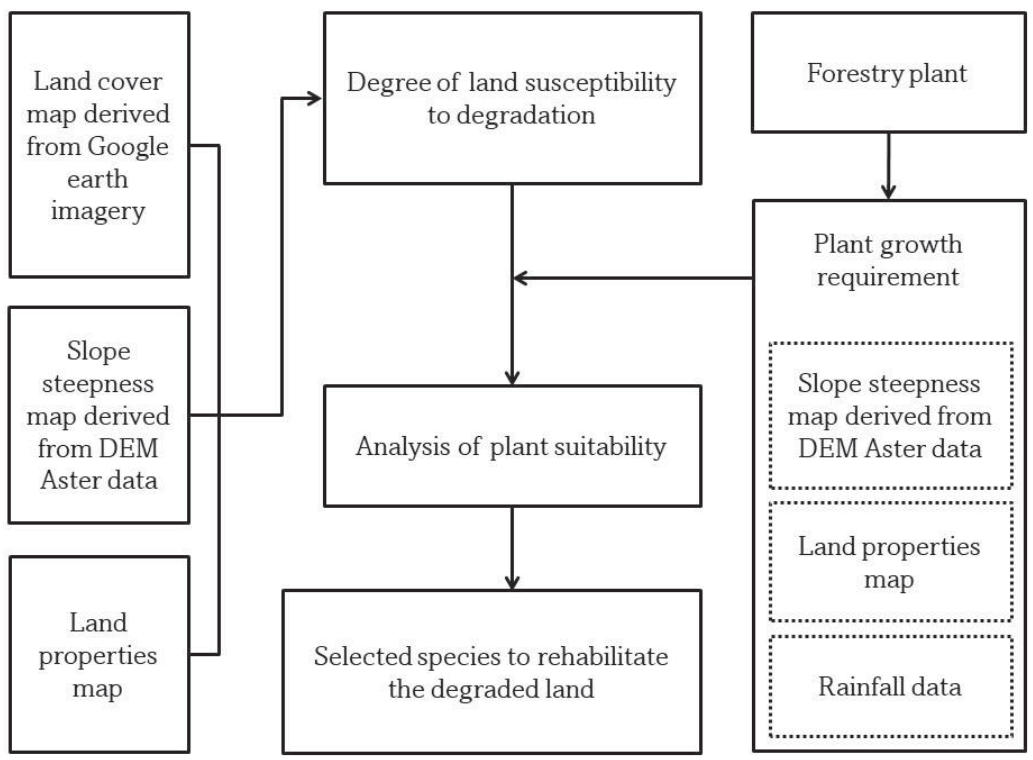

Figure 2. Research outline.

Table 1. Formulation of land susceptibility to degradation.

\begin{tabular}{|c|c|c|c|}
\hline No & Parameters & Value & Scores \\
\hline A & Nature (45\%) & & \\
\hline \multirow[t]{5}{*}{1} & \multirow{5}{*}{$\begin{array}{l}\text { Solum } \\
(10 \%)\end{array}$} & $>90 \mathrm{~cm}$ & 1 \\
\hline & & $60-<90 \mathrm{~cm}$ & 2 \\
\hline & & $30-<60 \mathrm{~cm}$ & 3 \\
\hline & & $15-<30 \mathrm{~cm}$ & 4 \\
\hline & & $<15 \mathrm{~cm}$ & 5 \\
\hline \multirow[t]{5}{*}{2} & \multirow{5}{*}{$\begin{array}{l}\text { Slope steepness } \\
(15 \%)\end{array}$} & $0-<8 \%$ & 1 \\
\hline & & $8-<15 \%$ & 2 \\
\hline & & $15-<25 \%$ & 3 \\
\hline & & $25-<45 \%$ & 4 \\
\hline & & $>45 \%$ & 5 \\
\hline \multirow[t]{5}{*}{3} & \multirow{5}{*}{$\begin{array}{l}\text { Outcrop } \\
(5 \%)\end{array}$} & $<20 \%$ & 1 \\
\hline & & $20-<40 \%$ & 2 \\
\hline & & $40-<60 \%$ & 3 \\
\hline & & $60-80 \%$ & 4 \\
\hline & & $>80 \%$ & 5 \\
\hline \multirow[t]{5}{*}{4} & \multirow{5}{*}{$\begin{array}{l}\text { Morfoerosion } \\
(10 \%)\end{array}$} & $0 \%$ & 1 \\
\hline & & $1-<20 \%$ & 2 \\
\hline & & $20-<40 \%$ & 3 \\
\hline & & $40-60 \%$ & 4 \\
\hline & & $>60 \%$ & 5 \\
\hline \multirow[t]{5}{*}{5} & \multirow{5}{*}{$\begin{array}{l}\text { Soil texture } \\
(5 \%)\end{array}$} & Sand, loamy sand & 1 \\
\hline & & Silty clay, sandy loam, clay & 2 \\
\hline & & Clay loam, silty clay loam & 3 \\
\hline & & Loam, sandy clay loam, sandy clay & 4 \\
\hline & & Silt, silt loam & 5 \\
\hline
\end{tabular}




\begin{tabular}{|c|c|c|c|}
\hline No & Parameters & Value & Scores \\
\hline B & Management $(55 \%) *$ ) & & \\
\hline 1 & Agricultural area (55 \%) & & \\
\hline \multirow[t]{7}{*}{ a } & \multirow{7}{*}{$\begin{array}{l}\text { Vegetation cover } \\
(40 \%)\end{array}$} & $50-80 \%$ forest $/$ plantation + seasonal crop & 1 \\
\hline & & $30-50 \%$ forest/plantation + densely seasonal crop & 2 \\
\hline & & $30-50 \%$ forest/plantation + sparse seasonal crop & 3 \\
\hline & & $10-30 \%$ forest $/$ plantation + densely seasonal crop & 3 \\
\hline & & Densely seasonal crop & 3 \\
\hline & & $10-30 \%$ forest $/$ plantation + sparse seasonal crop & 4 \\
\hline & & Sparse seasonal crop & 5 \\
\hline \multirow[t]{5}{*}{$\mathrm{b}$} & \multirow{5}{*}{$\begin{array}{l}\text { Soil conservation } \\
(15 \%)\end{array}$} & Level terrace & 1 \\
\hline & & Bench terrace & 2 \\
\hline & & Mixed terrace & 3 \\
\hline & & Contour terraces, hillside ditch, alley cropping & 4 \\
\hline & & No terrace & 5 \\
\hline 2 & \multicolumn{3}{|c|}{ Forest / plantation area (55 \%) } \\
\hline \multirow[t]{5}{*}{ a } & \multirow{5}{*}{$\begin{array}{l}\text { Vegetation cover } \\
(45 \%)\end{array}$} & Forest, plantation + cover-crop litter plantation & 1 \\
\hline & & Main vegetation $<50 \%+$ shrubs & 2 \\
\hline & & Shrubs & 3 \\
\hline & & Reed & 4 \\
\hline & & Bare land >50\% & 5 \\
\hline \multirow[t]{5}{*}{$\mathrm{b}$} & \multirow{5}{*}{$\begin{array}{l}\text { Soil conservation } \\
(10 \%)\end{array}$} & Contour terrace + crop & 1 \\
\hline & & Alley cropping & 2 \\
\hline & & Mulch contour & 3 \\
\hline & & Contour terrace & 4 \\
\hline & & No alley crop & 5 \\
\hline
\end{tabular}

Remarks: *) Management differentiated into "Agricultural area" and "Forest and plantation area"

Source: (Paimin et al., 2010)

Table 2. Classification of land susceptibility to degradation.

\begin{tabular}{ll}
\hline \multicolumn{1}{c}{ Value } & \multicolumn{1}{c}{ Degree of susceptibility to degradation } \\
\hline$>29.4$ & Very high \\
$>23.8-29.4$ & High \\
$>18.2-23.8$ & Moderate \\
$>12.6-18.2$ & Low \\
$\leq 12.6$ & Very low \\
\hline & Source : (Paimin et al., 2010)
\end{tabular}

Further analysis was undertaken to integrate the preliminary maps and the data from the field campaign. The resulting data were evaluated and classified based on Table 2. A number of previous studies have also applied this method in their efforts to identify the level of land degradation within the Tapan Micro Catchment in Karanganyar Regency (Basuki \& Wahyuningrum, 2014), Upper Solo
Sub Watershed in Wonogiri Regency (Basuki et al., 2016) and the Oyo Sub Watershed in Bantul Regency (Widya, 2015). The method was adopted here due to its ability to detect the potential of the degradation areas and also the occurrence of land degradation earlier. This is important because the dynamics in the watershed occur continuously due to both natural and human factors. 
Table 3. Criteria used in land suitability analysis.

\begin{tabular}{|c|c|c|c|c|c|c|}
\hline Parameter & $\begin{array}{c}\text { Class of } \\
\text { suitability }\end{array}$ & $\begin{array}{l}\text { Acacia } \\
\text { mangium }\end{array}$ & $\begin{array}{c}\text { Durio } \\
\text { zibethinus }\end{array}$ & $\begin{array}{l}\text { Artocarpus } \\
\text { champeden }\end{array}$ & $\begin{array}{c}\text { Theobroma } \\
\text { cacao }\end{array}$ & $\begin{array}{c}\text { Hevea } \\
\text { brassiliensis }\end{array}$ \\
\hline \multirow{4}{*}{$\begin{array}{l}\text { Rainfall } \\
(\mathrm{mm})\end{array}$} & S1 & $2500-3000$ & $2000-3000$ & $1000-2000$ & $1500-2000$ & $2500-3000$ \\
\hline & S2 & $\begin{array}{l}3000-4000 \\
2000-2500\end{array}$ & $\begin{array}{l}1750-2000 \\
3000-3500\end{array}$ & $\begin{array}{l}500-1000 \\
2000-3000\end{array}$ & $2500-3000$ & $\begin{array}{l}2000-2500 \\
3000-3500\end{array}$ \\
\hline & S3 & - & $\begin{array}{l}1250-1750 \\
3000-4000\end{array}$ & $\begin{array}{l}250-500 \\
3000-6000\end{array}$ & $\begin{array}{l}1250-1500 \\
3000-4000\end{array}$ & $\begin{array}{l}\text { 1500-2000, } \\
3500-4000\end{array}$ \\
\hline & $\mathrm{N}$ & - & $<1250,>4000$ & $<250,>6000$ & $<1250,>4000$ & $<1250,>4000$ \\
\hline \multirow{4}{*}{$\begin{array}{l}\text { Slope } \\
\text { steepness } \\
(\%)\end{array}$} & S1 & $0-8$ & $0-8$ & $0-8$ & $0-8$ & $0-8$ \\
\hline & S2 & $>8-15$ & $>8-15$ & $>8-15$ & $>8-15$ & $>8-15$ \\
\hline & S3 & $>15-30$ & $>15-30$ & $>15-30$ & $>15-30$ & $>15-30$ \\
\hline & $\mathrm{N}$ & $>30$ & $>30$ & $>30$ & $>30$ & $>30$ \\
\hline \multirow[t]{4}{*}{ Drainage } & S1 & $\begin{array}{l}\text { Well } \\
\text { drained }\end{array}$ & $\begin{array}{l}\text { Well drained, } \\
\text { Moderately } \\
\text { drained }\end{array}$ & $\begin{array}{l}\text { Well drained, } \\
\text { Moderately } \\
\text { drained }\end{array}$ & $\begin{array}{l}\text { Well drained, } \\
\text { Moderately } \\
\text { drained }\end{array}$ & Well drained \\
\hline & S2 & $\begin{array}{l}\text { Moderately } \\
\text { drained }\end{array}$ & $\begin{array}{l}\text { Slightly poorly } \\
\text { drained }\end{array}$ & $\begin{array}{l}\text { Slightly poorly } \\
\text { drained }\end{array}$ & $\begin{array}{l}\text { Slightly poorly } \\
\text { drained }\end{array}$ & $\begin{array}{l}\text { Moderately } \\
\text { drained }\end{array}$ \\
\hline & S3 & $\begin{array}{l}\text { Slightly } \\
\text { poorly } \\
\text { drained }\end{array}$ & $\begin{array}{l}\text { Poorly drained, } \\
\text { slightly } \\
\text { excessively } \\
\text { drained }\end{array}$ & $\begin{array}{l}\text { Poorly } \\
\text { drained, } \\
\text { slightly } \\
\text { excessively } \\
\text { drained }\end{array}$ & $\begin{array}{l}\text { Poorly drained, } \\
\text { slightly } \\
\text { excessively } \\
\text { drained }\end{array}$ & $\begin{array}{l}\text { Poorly drained, } \\
\text { slightly } \\
\text { excessively } \\
\text { drained }\end{array}$ \\
\hline & $\mathrm{N}$ & $\begin{array}{l}\text { Poorly } \\
\text { drained, } \\
\text { excessively } \\
\text { drained }\end{array}$ & $\begin{array}{l}\text { Very poorly } \\
\text { drained, } \\
\text { excessively } \\
\text { drained }\end{array}$ & $\begin{array}{l}\text { Very poorly } \\
\text { drained, } \\
\text { excessively } \\
\text { drained }\end{array}$ & $\begin{array}{l}\text { Very poorly } \\
\text { drained, } \\
\text { excessively } \\
\text { drained }\end{array}$ & $\begin{array}{l}\text { Very poorly } \\
\text { drained, } \\
\text { excessively } \\
\text { drained }\end{array}$ \\
\hline \multirow{4}{*}{$\begin{array}{l}\text { Solum } \\
(\mathrm{cm})\end{array}$} & S1 & $>100$ & $>100$ & $>100$ & $>100$ & $>100$ \\
\hline & S2 & $75-100$ & $75-100$ & $75-100$ & 75-100 & $75-100$ \\
\hline & S3 & $50-75$ & $50-75$ & $50-75$ & $50-75$ & $50-75$ \\
\hline & $\mathrm{N}$ & $<50$ & $<50$ & $<50$ & $<50$ & $<50$ \\
\hline \multirow{4}{*}{$\begin{array}{l}\text { Morfo- } \\
\text { erosion }\end{array}$} & S1 & Very low & Very low & Very low & Very low & Very low \\
\hline & S2 & Low & Low-moderate & Low-moderate & Low-moderate & Low-moderate \\
\hline & S3 & Moderate & Severe & Severe & Severe & Severe \\
\hline & $\mathrm{N}$ & Severe & Very severe & Very severe & Very severe & Very severe \\
\hline \multirow[t]{4}{*}{ Outcrop (\%) } & S1 & $<2$ & $<5$ & $<5$ & $<5$ & \\
\hline & S2 & $2-10$ & $5-15$ & $5-15$ & $5-15$ & $5-15$ \\
\hline & S3 & $>10-25$ & $15-25$ & $15-25$ & $15-25$ & $15-25$ \\
\hline & $\mathrm{N}$ & $>25-40$ & $>25$ & $>25$ & $>25$ & $>25$ \\
\hline
\end{tabular}

Remarks: S1 (Highly suitable); S2 (Moderately suitable); S3 (Marginally suitable); N (Not suitable) Source: (BBLSDLP, 2016)

The land suitability evaluation was forestry plants such as Acacia mangium, Durio conducted manually by matching the zibethinus, Artocarpus champeden, Theobroma biophysical conditions, i.e. climate, soil and cacao and Hevea brassiliensis. The land suitability plant growth requirements (Wahyuningrum et classification was conducted by sorting the al.,2003) using a geographicinformation system. land characteristics data based on the land The land suitability classes were divided into suitability criteria for each plant species. The highly suitable (S1), moderately suitable (S2), land suitability criteria used to analyse the marginally suitable (S3) and not suitable (N). suitability of each plant species is provided in The land suitability analysis was applied to Table 3. 


\section{Results and Discussion}

\subsection{Land cover}

The land cover was classified using satellite imagery from Google Earth 2014 and ground checks in 2016. Based on Table 4 , it can be seen that the dominant land cover was shrubs ( $25 \%$ of the watershed), followed by built areas ( $24 \%$ of the watershed), which contain settlements, an airport and port, while bare land covers $21 \%$ of the watershed. Most of the three dominant types of land cover were in flat areas. The spatial distributions of the various types of land cover are given in Figure 3.

Table 4. Land cover type at various slope classes.

\begin{tabular}{|c|c|c|c|c|c|c|c|}
\hline \multirow{2}{*}{ No } & \multirow{2}{*}{ Land cover } & \multicolumn{5}{|c|}{ Slope steepness (Ha) } & \multirow{2}{*}{ Total } \\
\hline & & $0-8 \%$ & $>8-15 \%$ & $>15-25 \%$ & $>25-45 \%$ & $>45 \%$ & \\
\hline 1 & Dryland Forest & 168 & 67 & 45 & 43 & 2 & 325 \\
\hline 2 & Mangrove & 709 & 38 & 9 & 0 & 0 & 757 \\
\hline 3 & Swamp Forest & 146 & 30 & 13 & 2 & 0 & 191 \\
\hline 4 & Plantation & 72 & 58 & 32 & 2 & 0 & 164 \\
\hline 5 & Shrubs & 1327 & 527 & 150 & 11 & 0 & 2015 \\
\hline 6 & Dryland Agriculture & 485 & 130 & 23 & 2 & 0 & 639 \\
\hline 7 & Built Areas & 1380 & 415 & 68 & 2 & 0 & 1864 \\
\hline 8 & Bare Land & 1161 & 422 & 82 & 2 & 0 & 1666 \\
\hline 9 & Fishponds & 14 & 0 & 0 & 0 & 0 & 14 \\
\hline 10 & Swamp & 73 & 1 & 0 & 0 & 0 & 75 \\
\hline 11 & Water Body & 182 & 14 & 2 & 0 & 0 & 199 \\
\hline & Total & 5718 & 1702 & 423 & 64 & 2 & 7910 \\
\hline
\end{tabular}
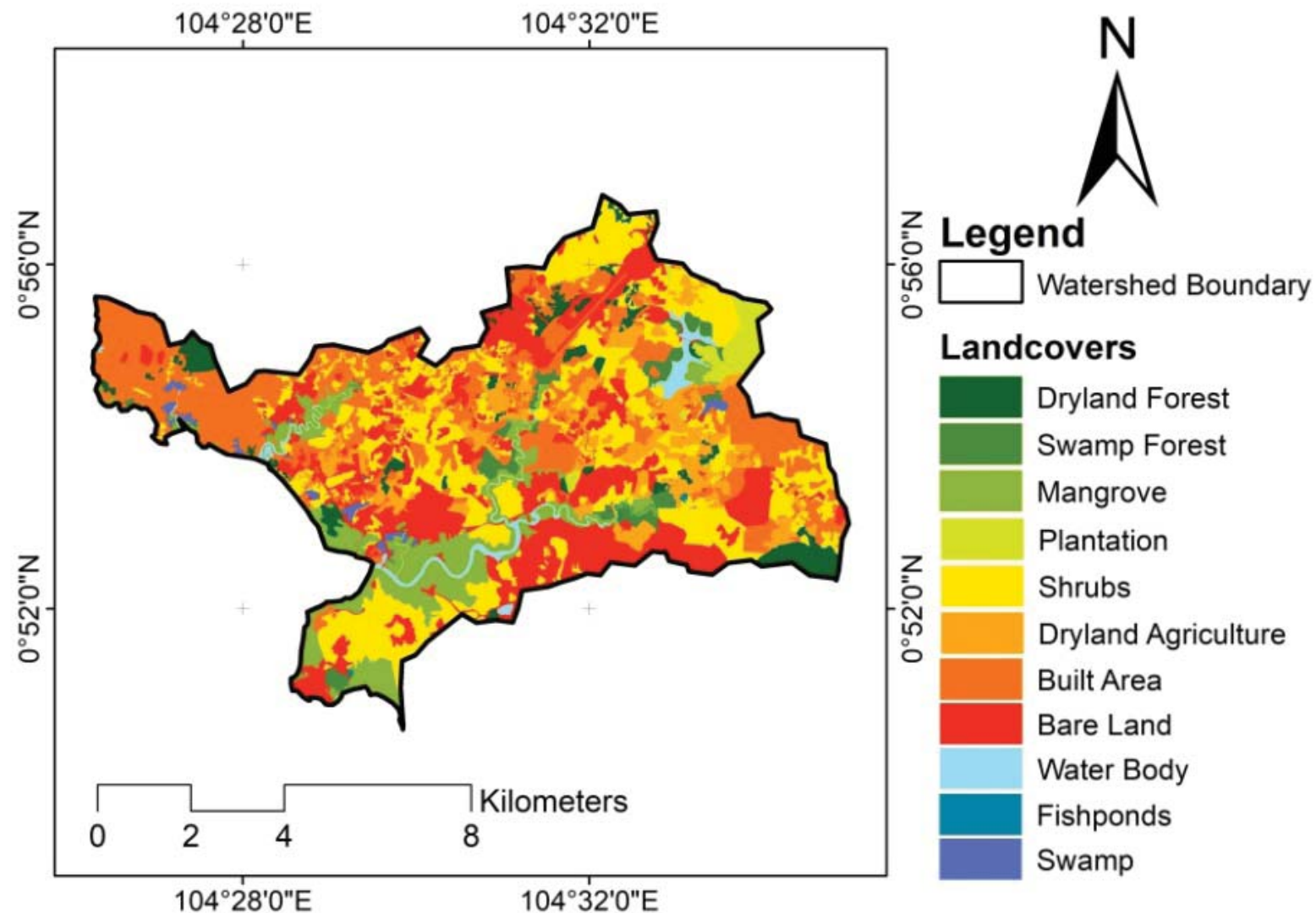

Figure 3. Land cover in Jang Watershed. 


\subsection{Land susceptibility to degradation}

The degree of land susceptibility was classified based on a quick assessment of land degradation. The study area is dominated by land that is moderately susceptible (49\%), followed by highly susceptible $(22 \%)$, with the susceptibility to degradation of the remaining land being very low (18\%) and low
(12\%) (Figure 4). The spatial distribution of the susceptibility of land to degradation for each type of land cover is shown in Table 5 . Most of the areas with high susceptibility to degradation were located in the bare land areas. Additionally, it is not only bare land that is susceptible to degradation, but also dryland forest.

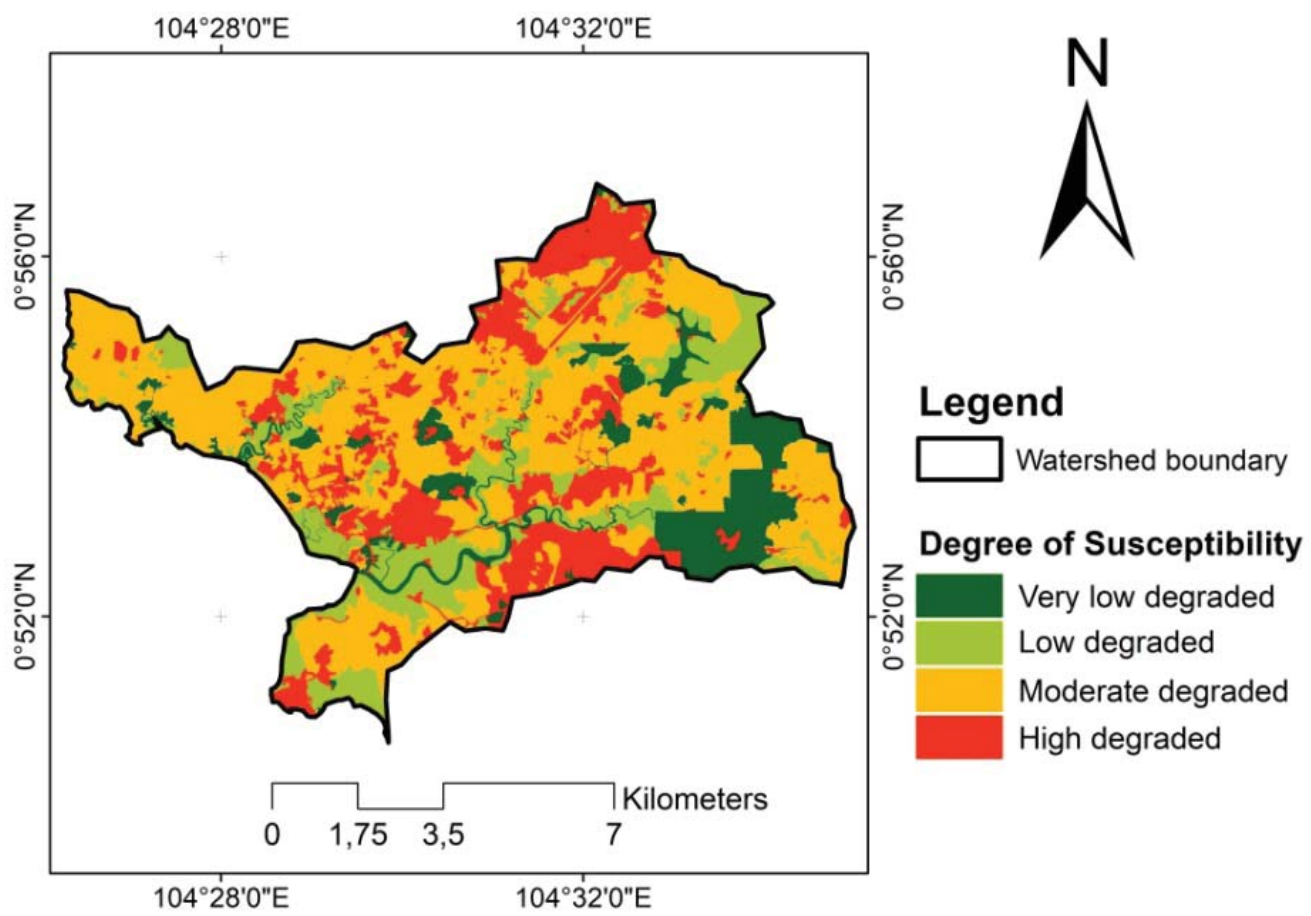

Figure 4. Spatial distribution of land degradation susceptibility.

Table 5. Distribution of land degradation susceptibility.

\begin{tabular}{|c|c|c|c|c|c|}
\hline \multirow{2}{*}{ No } & \multirow{2}{*}{ Land cover } & \multicolumn{4}{|c|}{ Degree of land susceptibility to degradation (Ha) } \\
\hline & & Very low & Low & Moderate & High \\
\hline 1 & Dryland Forest & 278.4 & 2.8 & 44.2 & 0.03 \\
\hline 2 & Mangrove & 756.6 & 0.1 & 0.1 & - \\
\hline 3 & Swamp Forest & 191.2 & 0.2 & 0.1 & 0.02 \\
\hline 4 & Plantation & 164.6 & 0.002 & 0.2 & 0.04 \\
\hline 5 & Shrubs & 0.8 & 348.7 & 1475.3 & 192.1 \\
\hline 6 & Dryland Agriculture & 0.2 & 0.02 & 634.0 & 6.1 \\
\hline 7 & Built Areas & 0.2 & 177.6 & 1687.9 & 0.1 \\
\hline 8 & Bare Land & 0.1 & 162.3 & 0.6 & 1504.4 \\
\hline 9 & Fishponds & - & - & - & - \\
\hline 10 & Swamp & - & - & - & - \\
\hline 11 & Water Body & - & - & - & - \\
\hline
\end{tabular}



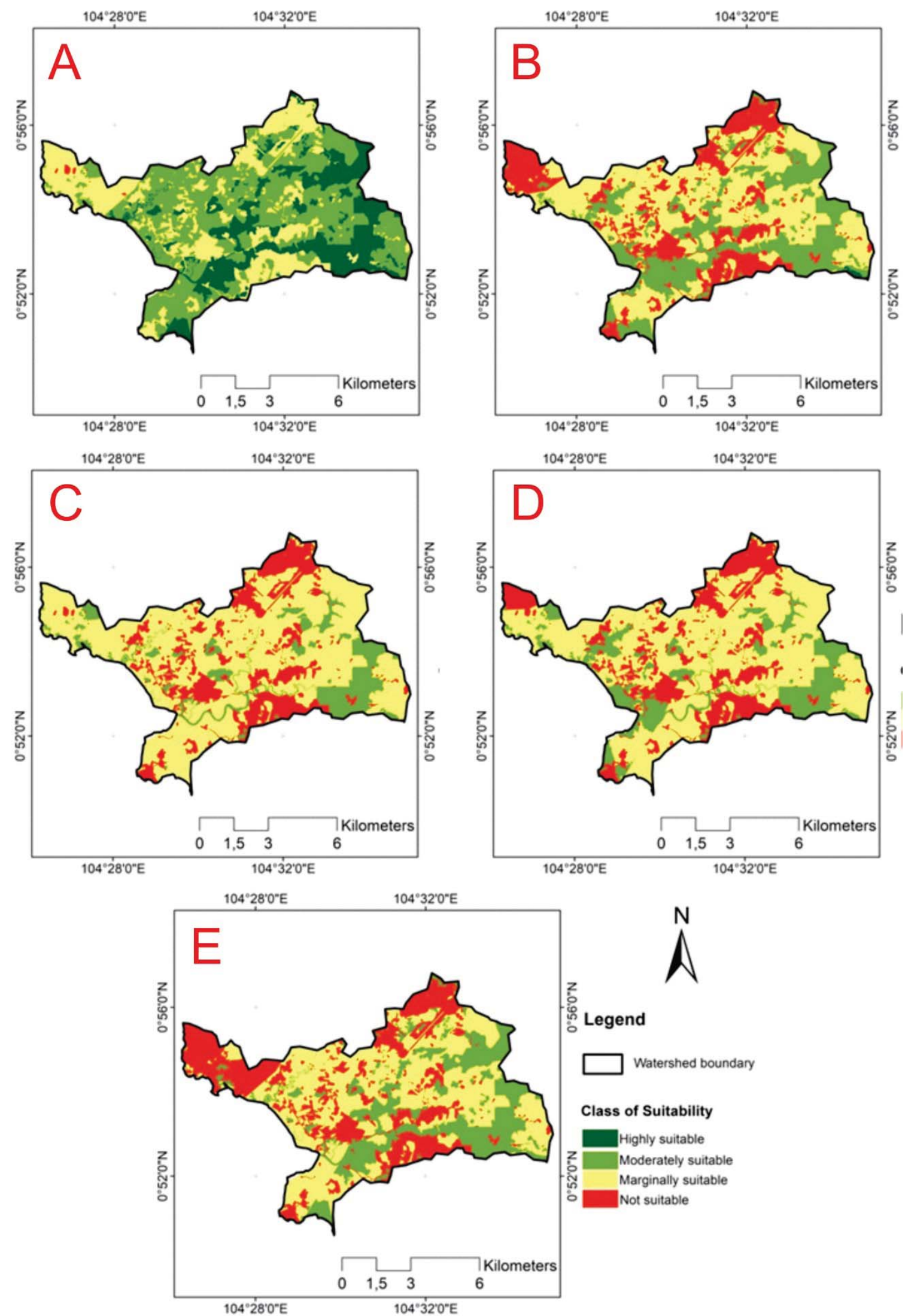

Class of Suitability

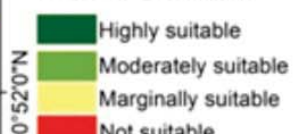

Marginally su

Figure 5. Spatial distribution of Acacia mangium suitability (A), Durio zibethinus suitability (B), Artocarpus champeden suitability (C), Theobroma cacao suitability (D), Hevea brassiliensis suitability (E). 
About $21 \%$ of the research sites consist of bare land. Based on the field observation, a majority of these are ex-mining lands. According to Ekyastuti et al. (2016), ex-mining areas have limitations in terms of planting. Clearly, the solum on these lands is very thin, which means that the selection of species for rehabilitation is based not only on their suitability but also their ability to improve the soil properties. This would pose quite a challenge to the rehabilitation of ex-mining areas.

\subsection{Recommendations for rehabilitating degraded land}

Land suitability analysis is a process for matching the characteristics of land resources to certain uses by employing a scientifically standardised technique (Wahyuningrum et al., 2003). The results of land suitability analysis can be used as a guide to finding solutions to the fragmentation and degradation of entire landscapes. Spatial distributions of the suitability of the various species based on the degraded land of Jang Watershed are shown in Figure 5.

The result of the land suitability analysis indicates that the majority of the land in the study area is moderately suitable for Acacia mangium (47\%), while Durio zibethinus (45\%), Artocarpus champeden (65\%), Theobroma cacao (59\%) and Hevea brassiliensis (47\%) scored highest for the marginally suitable class. The classes of suitability are presented in detail in Table 6. Based on the ground check, only the B and $C$ horizons remain in the bare land areas due to the loss of topsoil. Organic material or compost is therefore required to improve the physical properties of these soils. In addition, chemical fertilisers must be added to both stimulate plant growth and provide the right conditions for growth to occur.

Table 6. Spatial assessment of land suitability based on degraded land in Jang Watershed.

\begin{tabular}{|c|c|c|c|c|c|}
\hline \multirow{2}{*}{\multicolumn{2}{|c|}{$\begin{array}{c}\text { Species suitability } \\
\text { Very low } \\
\text { degraded }\end{array}$}} & \multicolumn{4}{|c|}{ Susceptibility of land to degradation (Ha) } \\
\hline & & \multirow{2}{*}{$\begin{array}{c}\begin{array}{c}\text { Very low } \\
\text { degraded }\end{array} \\
949\end{array}$} & \multirow{2}{*}{$\begin{array}{c}\begin{array}{c}\text { Low } \\
\text { degraded }\end{array} \\
942\end{array}$} & \multirow{2}{*}{$\begin{array}{c}\begin{array}{r}\text { Moderate } \\
\text { degraded }\end{array} \\
7\end{array}$} & \multirow{2}{*}{$\begin{array}{c}\begin{array}{c}\text { High } \\
\text { degraded }\end{array} \\
4\end{array}$} \\
\hline Acacia & S1 & & & & \\
\hline mangium & S2 & 35 & 443 & 3274 & 10 \\
\hline & S3 & 3 & 1 & 578 & 1689 \\
\hline & $\mathrm{N}$ & 0 & 0 & 0 & 20 \\
\hline \multirow{4}{*}{$\begin{array}{l}\text { Durio } \\
\text { zibethinus }\end{array}$} & S1 & 0 & 20 & 0 & 0 \\
\hline & S2 & 979 & 1288 & 29 & 4 \\
\hline & S3 & 4 & 76 & 3498 & 10 \\
\hline & $\mathrm{N}$ & 3 & 1 & 332 & 1709 \\
\hline \multirow{4}{*}{$\begin{array}{l}\text { Artocarpus } \\
\text { champeden }\end{array}$} & S1 & 0 & 0 & 0 & 0 \\
\hline & S2 & 978 & 96 & 4 & 3 \\
\hline & S3 & 5 & 1290 & 3844 & 11 \\
\hline & $\mathrm{N}$ & 3 & 1 & 10 & 1709 \\
\hline \multirow{4}{*}{$\begin{array}{l}\text { Theobroma } \\
\text { cacao }\end{array}$} & S1 & 0 & 0 & 0 & 0 \\
\hline & $\mathrm{S} 2$ & 978 & 464 & 5 & 3 \\
\hline & S3 & 5 & 921 & 3719 & 11 \\
\hline & $\mathrm{N}$ & 3 & 1 & 135 & 1709 \\
\hline \multirow{4}{*}{$\begin{array}{l}\text { Hevea } \\
\text { brassiliensis }\end{array}$} & S1 & 0 & 1 & 0 & 0 \\
\hline & S2 & 978 & 939 & 13 & 4 \\
\hline & S3 & 5 & 445 & 3269 & 10 \\
\hline & $\mathrm{N}$ & 3 & 1 & 577 & 1709 \\
\hline
\end{tabular}


The rehabilitation of degraded land is a governmental programme requiring specific knowledge of soil characteristics, appropriate rehabilitation techniques, the proper selection of plant species, planting techniques and vegetation maintenance (Sudarmadji \& Hartati, 2016). In order to ensure suitable plants are used to rehabilitate degraded land, the selected species should have moderate to high suitability for the classes of moderate to high degradation. Table 6 shows that Acacia mangium is suitable for growing in the areas covering $3295 \mathrm{Ha}$ that are characterised by a moderate to high degree of land degradation (59\%), while Durio zibethinus can be planted on $33 \mathrm{Ha}(0.6 \%)$. Artocarpus champeden, Theobroma cacao and Hevea brassiliensis can be utilised on 8 На $(0.2 \%), 8$ На $(0.2 \%)$ and 17 На $(0.3 \%)$, respectively. Thus, Acacia mangium is the species that is recommended for rehabilitating degraded land in the Jang Watershed.

Acacia mangium is a fast-growing tree (Krisnawati et al., 2011) and the species is a pioneer that will grow in degraded lands. Based on Widiatmaka et al. (2010)chemical and biological properties of soil as growth media, in order to support the rehabilitation plans. The objective of this study were: (i, the rehabilitation of former mining land requires improvement to the physical, chemical and biological properties of the soil. Therefore, the planting of Acacia mangium is expected to improve the soil properties of the degraded lands. The root system of A. mangium can penetrate the compacted soil and stimulate the weathering process of its parent material. In addition, decomposed litter fall may improve the organic matter of the soil and release greater amounts of nutrients below the stand, thereby improving the soil properties (Yamashita et al., 2008).

In addition to the technical problems described above, the plants selected should be from species that are the most acceptable to the society in question. In this case, the selected plants are not only able to improve the degraded land but can also support the well-being of the society.

\section{Conclusion}

About $22 \%$ of Jang Watershed was found to be highly susceptible to degradation, with the majority comprising bare land. Revegetation of the degraded land has to take into consideration a land suitability analysis. It is essential that pioneer trees are planted prior to introducing other species that have greater requirements for growth. A pioneer such as Acacia mangium is expected to improve the physical, chemical and biological properties of the soil. Further research should be conducted into the economic aspect of those species deemed suitable for rehabilitating the degraded land. This is essential since such species are also the materials for some industries.

\section{References}

Adi, R. N., \& Wijaya, W. W. (2016). Karakteristik hujan Pulau Batam dan Pulau Bintan, Propinsi Kepulauan Riau. In A. B. Supangat, N. P. Nugroho, S. A. Cahyono, I. G. A. K. Rahmi, M. Suprapto, K. D. Priyono, ... E. Irawan (Eds.), Peran Pengelolaan DAS untuk Mendukung Ketahanan Air (pp. 76-88). Surakarta: Balai Litbang Teknologi Pengelolaan DAS bekerjasama dengan Pascasarjana UNS dan Fakultas Geografi UMS.

Basuki, T. M., \& Wahyuningrum, N. (2014). The potential of remote sensing for assessment of land susceptibility to degradation: A case study in Tapan Micro Catchment. In Forestry Research for Sustainable Forest Management and Community Welfare (pp. 575-585). Jakarta: Ministry of Forestry, Forestry Research and Development Agency. Retrieved from http:/ / www.forda-mof.org/index.php/content/publikasi/post/387

Basuki, T. M., \& Wahyuningrum, N. (2016). Diameter and height from various ages of Swietenia sp. in relation to its land suitability and stand table at different class index (bonita) in 
Grobogan and Temanggung Districts. In Proceedings of International Conference of Indonesia Forestry research to support sustainable timber production and self-sufficiency in food, energy, and water (pp. 329-337). Bogor: Development And Innovation Agency. Ministry of Environment and Forestry Research. Retrieved from http://www.forda-mof.org/files/Proceedings_of_International_Conference_of_Indonesia_Forestry_Researchers_III-2015a.pdf

Basuki, T. M., Wijaya, W. W., \& Wahyuningrum, N. (2016). Spatial distribution of land susceptibility to degradation and recomendation for its improvement: A case study in the Upper Solo Sub-Watershed. Journal of Degraded and Mining Lands Management, 4(1), 689-696. https:/ / doi.org/10.15243/jdmlm.2016.041.689

BBLSDLP. (2016). Balai Besar Litbang Sumberdaya Lahan Pertanian. Retrieved December 20, 2016, from https:/ / bbsdlp.litbang.pertanian.go.id/ind/

Ekyastuti, W., Astiani, D., \& Roslinda, E. (2016). Prospect of indigenous plant species for revegetation in the tailings area of ex community gold mine. Biodiversitas, Journal of Biological Diversity, 17(2), 764-768. https://doi.org/10.13057/biodiv/d170252

Eni, I. (2012). Effects of land degradation on soil fertility: A case study of Calabar South, Nigeria. Environmental Land Use Planning, 21-34. https:/ / doi.org/10.5772/51483

Hasan, M. F., Parman, S., \& Aji, A. (2016). Sebaran spasial lahan kritis untuk prioritas rehabilitasi berbasis sistem informasi geografis dan penginderaan jauh di DAS Juwana Hulu Muria. Geo Image, 5(1), 1-5. Retrieved from http://journal.unnes.ac.id/sju/index.php/geoimage

Herrick, J. E., Neff, J., Quandt, A., Salley, S., Maynard, J., Ganguli, A., \& Bestelmeyer, B. (2019). Prioritizing land for investments based on short- and long-term land potential and degradation risk: A strategic approach. Environmental Science and Policy, 96, 52-58. https://doi. org/10.1016/j.envsci.2019.03.001

Hu, Q., Wu, W., Xia, T., Yu, Q., Yang, P., Li, Z., \& Song, Q. (2013). Exploring the use of google earth imagery and object-based methods in land use/cover mapping. Remote Sensing, 5(11), 6026-6042. https:/ / doi.org/10.3390/rs5116026

Krisnawati, H., Kallio, M., \& Kanninen, M. (2011). Acacia mangium Willd: Ekologi, silvikultur dan produktivitas (Acacia mangium Willd. : Ecology, silviculture, and productivity). Bogor: CIFOR. Retrieved from http://www.cifor.org/publications/pdf_files/Books/BKrisnawati1106. pdf

Kubangun, S. H., Haridjaja, O., \& Gandasasmita, K. (2014). Model spasial bahaya lahan kritis di Kabupaten Bogor, Cianjur, dan Sukabumi (Spatial model of critical land hazard at Bogor, Cianjur and Sukabumi Regencies). Majalah Ilmiah Globe, 16(2), 149-156.

Marchetti, M., Vizzarri, M., Sallustio, L., di Cristofaro, M., Lasserre, B., Lombardi, F., ... Santopuoli, G. (2018). Behind forest cover changes: is natural regrowth supporting landscape restoration? Findings from Central Italy. Plant Biosystems, 152(3), 524-535. https:// doi.org /10.1080/11263504.2018.1435585

Mawardi, I. (2010). Kerusakan daerah aliran sungai dan penurunan daya dukung sumberdaya air di Pulau Jawa serta upaya penanganannya. Jurnal Hidrosfir Indonesia, 5(2), 1-11.

Narulita, I., Rahmat, A., \& Maria, R. (2008). Aplikasi sistem informasi geografi untuk menentukan daerah prioritas rehabilitasi di cekungan Bandung. Jurnal Riset Geologi Dan Pertambangan Jilid, 18(1), 23-35.

Nugroho, S. P., \& Prayogo, T. (2008). Penerapan SIG untuk penyusunan dan analisis lahan kritis pada satuan wilayah pengelolaan DAS Agam Kuantan, Provinsi Sumatera Barat. Jurnal 
Teknik Lingkungan, 9(2), 130-140.

Paimin, Sukresno, \& Purwanto. (2010). Sidik cepat degradasi Sub Daerah Aliran Sungai (Sub DAS) (Cetakan kedua). Bogor: Pusat Penelitian dan Pengembangan Konservasi dan Rehabilitasi, Balitbang Kehutanan.

Pratiwi, Hartoyo, M. E., Narendara, B. H., \& Susi, I. W. (2014). Kesesuaian jenis pohon pada lahan kritis di Sub DAS Lesti, Jawa Timur (Suitability of tree species in critical land of Lesti Sub Watershed, East Java). Jurnal Penelitian Hutan Dan Konservasi Alam, 11(2), 183-204.

Sudarmadji, T., \& Hartati, W. (2016). The process of rehabilitation of mined forest lands toward degraded forest ecosystem recovery in Kalimantan, Indonesia. Biodiversitas, Journal of Biological Diversity, 17(1), 185-191. https:/ / doi.org/10.13057/ biodiv/d170127

Tarigan, S. D. (2012). Methods for delineating degraded land at Citarum Watershed, West Java, Indonesia. Jurnal TANAH TROPIKA (Journal of Tropical Soils), 17(3), 267-274. https:/ / doi. org/10.5400/jts.2012.17.3.267

Wahyuningrum, N., \& Basuki, T. M. (2014). Evaluasi kemampuan lahan bersolum dangkal (Land use capability evaluation on shallow solum critical land). Indonesian Forest Rehabilitation Journal, 2(1), 39-54. https:/ / doi.org/10.9868/ifrj.2.1.39-54

Wahyuningrum, N. C., Nugroho, S. P., Wardojo, H. B., Savitri, E., \& Sudimin, S. (2003). Klasifikasi Kemampuan Dan Kesesuaian Lahan. Info DAS Surakarta, (15).

Widiatmaka, W., Suwarno, S., \& Kusmaryandi, N. (2010). Karakteristik pedologi dan pengelolaan revegetasi lahan bekas tambang nikel: Studi kasus lahan bekas tambang nikel Pomalaa, Sulawesi Tenggara (Pedological characteristics and revegetation management of nickel post mining land: Case study of nickel post mining land at Pomalaa, South East Sulawesi). Jurnal Ilmu Tanah Dan Lingkungan, 12(2), 1-10. Retrieved from http://jesl.journal.ipb.ac.id/ index.php/jtanah/article/view/16596/12159

Widya, S. B. (2015). Analisis kekritisan dan potensi lahan Sub DAS Oyo (Analysis of criticality and potential land on Oyo Sub Watershed). Universitas Gadjah Mada. Retrieved from http:/ / etd.repository.ugm.ac.id/index.php?mod=penelitian_detail\&sub=PenelitianDetail\&act=view\&typ=html\&buku_id=83209\&obyek_id=4

Yamashita, N., Ohta, S., \& Hardjono, A. (2008). Soil changes induced by Acacia mangium plantation establishment: Comparison with secondary forest and Imperata cylindrica grassland soils in South Sumatra, Indonesia. Forest Ecology and Management, 254(2), 362-370. https:/ / doi.org/10.1016/j.foreco.2007.08.012 